\title{
Bhutan in 1996: Continuing Stress
}

\section{Author(s): Michael Hutt}

Source: Asian Survey, Vol. 37, No. 2, A Survey of Asia in 1996: Part II (Feb., 1997), pp. 155159

\section{Published by: University of California Press}

Stable URL: https://www.jstor.org/stable/2645482

Accessed: 21-06-2019 12:25 UTC

JSTOR is a not-for-profit service that helps scholars, researchers, and students discover, use, and build upon a wide range of content in a trusted digital archive. We use information technology and tools to increase productivity and facilitate new forms of scholarship. For more information about JSTOR, please contact support@jstor.org.

Your use of the JSTOR archive indicates your acceptance of the Terms \& Conditions of Use, available at https://about.jstor.org/terms 


\section{BHUTAN IN 1996}

\section{Continuing Stress}

\section{Michael Hutt}

Seen through the window of Kuensel, the kingdom's only newspaper, Bhutan is a country where problems often arise when the outside world intrudes. Tourists endanger its culture and their numbers must be limited; "anti-nationals," mostly of Nepalese ethnic extraction, endanger its sovereignty and their demands must be denied. Nonetheless, 1995 was declared a record year for tourism, with 4,765 non-Indian tourists bringing in US\$5.887 million, an increase of some 800 visitors and nearly $\$ 2$ million in income over 1994. Half of the tourists came from either Japan or the U.S.; the 1996 numbers increased again.

For the "anti-nationals" 1996 was less auspicious. These people, now numbering 91,000 , live as Bhutanese refugees in camps in southeastern $\mathrm{Ne}$ pal (in 1990, Bhutan's official total population was 600,000 ). Bhutan's political elite believes that its hold on power is threatened by the existence of these camps, and more generally by demographic trends in northeastern India, but there are signs that the outside world is beginning to exert some pressure on Bhutan to moderate its stance. Kuensel's front page records visits to Bhutan by a succession of foreign delegations and individuals; often these are in connection with a particular development project, or they are routine visits by Indian officials that present both sides with an opportunity to emphasize the warmth and cordiality of Indo-Bhutanese relations. Increasingly, however, influential visitors come to Bhutan to discuss the refugee question or the issue of human rights within Bhutan. The president of the Executive Committee of the United Nations High Commissioner for Refugees (UNHCR) was in Thimphu in January, followed in April by the U.N.'s Working Group on Arbitrary Detention, a delegation from the International Committee of the Red Cross in May, and a group of senior UNHCR officials in August.

University of London.

Michael Hutt is Lecturer in the School of Oriental and African Studies,

(c) 1997 by The Regents of the University of California 
Arbitrary detention. The U.N. Working Group on Arbitrary Detention, which had visited Bhutan in October 1994, returned for a second visit in April-May 1996 to review the implementation of its earlier recommendations, and also to review its 1994 decision that the detention of Tek Nath Rizal, Bhutan's leading political prisoner, had not been arbitrary. In a revised decision dated May 24, 1996, the Group declared that the first three years of Rizal's detention, up until he was first produced before a court in December 1992, had in fact been arbitrary, while his detention in subsequent years was not arbitrary.

A notable development in Bhutan during the year was the establishment in March of training courses for jabmis, the traditional Bhutanese legal counsels. At the end of the first month-long course, 72 graduates were issued with licenses, and further courses during the year produced more licensed jabmis. This initiative may well have been a reaction to a reference in the U.N. Working Group's report on its 1994 mission to the "complete absence of a legal community, the existence of which is necessary for the functioning of any legal system."

\section{Relations with India}

The king of Bhutan led a delegation on a four-day visit to Delhi in March during which agreements were signed on two major joint ventures-the Tala hydroelectric project and the Dungsum cement plant, both of which began work in June - and discussions were held on issues of security and stability. India also extended the term of an existing standby credit facility. "India's larger size and population are viewed by Bhutan not as a threat but as a market of unlimited potential. India has no doubts about the wisdom of helping to harness Bhutan's natural resources," stated the Kuensel editorial on March 9. Later that month, Indian officials visited Thimphu to review the progress of Bhutan's 7th Five-Year Plan, and a return visit to New Delhi took place in September to finalize the 8th Plan. Bhutan's relations with India are becoming increasingly crucial, not just for the kingdom's economic development but for the maintenance of its political culture and the continued denial of its exiled dissidents' demands. In the October issue of the Bhutan Review, a skeptical monthly commentary on Bhutanese affairs published by the Human Rights Organization of Bhutan (HUROB) in Kathmandu, much was made of the fact that Bhutan had chosen to side with India in the vote in the United Nations on the Comprehensive Test Ban Treaty, thus becoming one of only three countries (India, Libya, Bhutan) to oppose the Treaty.

\section{The Bilateral Process and the AMCC}

The governments of Bhutan and Nepal failed to make any progress toward a solution of the refugee problem during the seventh meeting of the Ministerial Joint Committee in Kathmandu in April. The Kuensel editorial of April 13 
blamed this failure on Nepal, which it said wanted "dramatically relaxed criteria for the identification of the people in the camps" so that "every man, woman, and child must be settled in Bhutan on the basis of his or her verbal statement." But the editorial ended with an expression of concern for the people in the camps, which was unusual. Despite this glimmer of hope and despite the passing in March of a European Parliament resolution urging a UNHCR-supervised repatriation of Bhutanese refugees, the issue seems to have sunk low in the Nepal government's list of priorities, while the Bhutan government, which must surely know how many of the refugees would be entitled to repatriation if the much-heralded verification process ever began, is unlikely to press for the promised eighth meeting.

Frustrated by the continued failure of the bilateral process, activists in the camps in Nepal established an Appeal Movement Coordinating Council (AMCC), which sent an "appeal letter" to the king of Bhutan in September 1995. No reply was received and so, in a strategy announced in the original letter, the first "appeal march" to Bhutan was launched from the refugee camps in January 1996. Its stated aim was to present a letter to the king asking for the release of Tek Nath Rizal and the initiation of a process of national reconciliation. After years of insisting that the refugee problem was a bilateral issue between Bhutan and Nepal, India was forced during 1996 to adopt a public stance, and in the event this stance was strongly supportive of the Bhutanese government. The West Bengal police imposed provisions of the Indian Penal Code across northern West Bengal, and successive waves of "appeal marchers" who left the camps and crossed the Indo-Nepalese border were promptly arrested. The marchers on several occasions were released by the magistrates of one district, only to be rearrested when they crossed into another district. On July 4, however, detention of the 791 detained marchers was declared illegal in the Calcutta High Court, and all were released.

In mid-August a group of 50 refugee marchers managed to slip inside Bhu$\tan$; refugee sources claim they were eventually expelled in the small hours of August 16, with several being pushed out of moving vehicles. In November an attempt by 51 marchers to enter Bhutan via Phuentsholing was thwarted by Indian police. Kuensel reported on January 27 in quite neutral tones that a "long march" to Bhutan from the refugee camps had been stopped by Indian authorities, but in its July 6 issue, published just after the 74th session of the National Assembly had begun, a lengthy report appeared under the headline, “'Peace March' Is a Threat to the Nation's Security." It said that the king had "expressed his deep appreciation to the government of India for the steps taken to prevent the so-called peace marchers from creating law and order problems and not allowing anti-Bhutan activities to be carried out from Indian soil." As in previous years, much of the National Assembly's time was given over to denouncing vigorously the allegations of the "anti-nationals"; 
the Assembly also called for a halt in bilateral talks with Nepal and in the employment of Nepalese nationals, as well as for the early resettlement of northern Bhutanese on land lying vacant in the south.

\section{Border Tensions}

Kuensel reported around a dozen instances of armed robbery and assault in southern Bhutan up to mid-November 1996. In most of these, southern Bhutanese were attacked in their homes and reportedly relieved of cash, gold, and sometimes citizenship cards. Frequently, the culprits were reported to include people from the refugee camps, and on several occasions headlines branded them "terrorists" even if texts of the articles did not use that term. Other reports in the newspaper included: two separate incidents of "illegal immigrants" of Nepalese ethnicity prevented from entering Bhutan; a reference to an "anti-national camp" in the Jalpaiguri District of West Bengal; a report of a captured "terrorist" having undergone 11 months of training in the use of explosives and firearms; the arrest in Samtse of two men carrying "explosives and anti-national leaflets"; the discovery of a quantity of dynamite; and hand grenade and bomb throwing at Phuentsholing.

Clearly, the Bhutanese government wishes the world to believe that it has a terrorism problem on its hands, but as HUROB argues, many of these incidents appear to be criminal acts of assault and theft, not politically motivated murder or sabotage, while other reports beg many questions. For instance, where did the aforementioned "terrorist" receive his 11 months of training? And if an "anti-national camp" does indeed exist on Indian soil, why does the Indian government tolerate its presence but arrest the appeal marchers? On the other hand, cross-border tension does appear to have grown, perhaps as a result of the appeal march campaigns, and neither Kuensel nor the dissident publications have explained fully what is going on.

\section{Conclusion}

During 1996, the political problem that has dogged Bhutan for the past six years festered on, with no prospect of a solution in sight. Development projects continued apace, but as the years pass the kingdom depends increasingly upon India for support and protection-a dependence some observers fear might have a negative impact in the longer term upon Bhutan's traditional self-reliance. There is much else that could be said about Bhutan in 1996, and much that would be positive. Compulsory labor conscription was phased out; the Austrian-funded Rangjung Hydroelectric Project was completed; civil servants, village headmen, and National Assembly members received very substantial pay rises; a new Je Khenpo (Bhutan's highest Buddhist spiritual authority) was installed; the Bhutan Trust Fund for environmental projects grew to $\$ 20$ million; Denmark made a major donation to 
support the development of the Bhutanese media; and much was done to preserve and enrich Bhutanese arts, crafts and culture. But the backdrop is one of continuing stress, with the government at odds with a large section of its people who have no choice but to continue living in exile in Nepal. This is a situation that should be resolved, in the words of the Kuensel editorial of April 13, "for the sake of the people in both countries and, even more so, for the people in the refugee camps." 